DOI: http://dx.doi.org/10.33846/hn50404

http://heanoti.com/index.php/hn

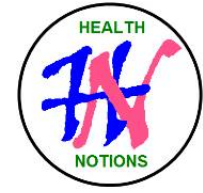

RESEARCH ARTICLE

URL of this article: http://heanoti.com/index.php/hn/article/view/hn50404

\title{
The Effect of Straight Leg Raise Exercise with Static Bicycles on Increasing Quadriceps Muscle Strength in Knee Osteoarthritis Patients
}

\author{
Endang Mien Mas'ud ${ }^{1}$, Hasbiah $^{2}$, Hendrik $^{3(C A)}$ \\ ${ }^{1}$ Postgraduate Student of Sports Physiology, Faculty of Medicine, Universitas Udayana, Bali, \\ Indonesia; endangmasud02gmail.com \\ ${ }^{2}$ Department of Physiotherapy, Poltekkes Kemenkes Makassar, Indonesia; hasbiahfisiopoltekkes@ gmail.com \\ ${ }^{3(\mathrm{CA})}$ Department of Physiotherapy, Poltekkes Kemenkes Makassar, Indonesia; padanghendrik10@ gmail.com \\ (Corresponding Author)
}

\begin{abstract}
Knee osteoarthritis is a degenerative disease characterized by pain and limited motion of the joints resulting in muscle weakness. Late consequences can lead to limited motion and shortening of intra and extra joint components. This study aimed to analyze the effect of straight leg raise and static bicycles on the increase in quadriceps muscle strength in patients with knee osteoarthritis. This study was an experimental study with a two-group pretest-posttest design. The research was conducted at the Salewangan Maros Hospital. The population was knee joint osteoarthritis patients aged 40-60 years and experienced quadriceps muscle weakness. The sample met the inclusion criteria obtained by simple random sampling technique so that sample size was 28 subjects, then randomized into two treatment groups, each of 14 subjects. The research data was the strength of the quadriceps muscles using manual muscle testing which was done twice, namely before and after the straight leg raise exercise with a static bicycle. Because the data distribution were not normal, the nonparametric analysis was used. The results of the Wilcoxon test analysis showed that there was a significant effect of giving straight leg raise $(\mathrm{p}=0.002)$ and static bicycles $(\mathrm{p}=0.005)$ training on increasing quadriceps muscle strength. The results of the Mann-Whitney test showed no significant differences between groups on the increase in quadriceps muscle strength $(\mathrm{p}=0.481)$. The results showed that straight leg raises and static bicycles increased muscle strength and there was no difference between the two exercises.
\end{abstract}

Keywords: knee osteoarthritis; exercise; muscle strength, static bicycle; straight leg raise

\section{INTRODUCTION}

Basic Health Research (Riskesdas) in 2018 from interviews at $>15$ years of age, the national prevalence of joint disease or rheumatism was $7.30 \%$. Aceh Province is a province with the highest prevalence of osteoarthritis, which is around $13.26 \%$ and the province with the lowest prevalence is Bangka Belitung which is around $4.51 \%$, while in South Sulawesi the prevalence rate is around $6.39 \%{ }^{(1)}$. Osteoarthritis (OA) affects nearly 60 million people in America (2), (3), Approximately 10-30\% of the world's elderly have osteoarthritis, especially in rural areas ${ }^{(4)}$, and attacking women more than men, where the prevalence increases with increasing $\operatorname{age}^{(1),(5)}$.

Osteoarthritis is a chronic degenerative disease that affects the joints. Osteoarthritis in the knee joint will cause systemic disorders of motion in the bones and joints and cause a decrease in muscle strength around the joints which in turn causes significant disability ${ }^{(6)}$. The osteoarthritis process causes pain and inflammation resulting in degeneration of the bones around the joints, loss of cartilage, abnormal bone formation at the ends of the joints as well as causing joint space narrowing. The result of osteoarthritis results in joint disorders in the form of decreased function, pain, loss of range of motion, and joint instability, which ultimately leads to muscle weakness ${ }^{(5)}$. The most visible disorders in knee osteoarthritis are pain and limited movement as the main factors 
disrupting knee joint function in activities. Osteoarthritis will cause disturbances in the intra and extra-articular systems ${ }^{(5),(6),(7)}$.

Pain in osteoarthritis of the knee is closely related to decreased muscle strength around the knee, namely the posterior, anterior, medial, and lateral sides. Long periods of inactivity due to joint pain lead to atrophic disuse and muscle strength that is reduced by $3 \%$ in one week. The weakness of the limb muscles is one of the most common conditions in knee osteoarthritis. Functional disorders in people with osteoarthritis are caused by pain. This pain is associated with decreased muscle strength. This muscle is the main stabilizer of the knee joint which functions as a protector of the knee joint structure. This pain will also reduce the area of motion of the joints because with this pain the joints are rarely moved so that the muscles experience a decrease in strength ${ }^{(8)}$, ${ }^{(9)}$. Decreased strength accompanied by loss of functional muscle contraction will result in non-synergistic (nonphysiological) contractions thereby increasing excessive stress on one of the joint contact surfaces, which in turn will increase the progression of the joint degenerative process. The presence of muscle weakness is a stronger predictor of disability than joint space narrowing and pain complaints ${ }^{(4),(10),(11)}$. The pain and disability will increase with the appearance of the weakness of the quadriceps muscles. Muscle is an important ability in helping to stabilize joints, whereas weakness of the quadriceps muscles can lead to worsening osteoarthritis and even cause psychosocial disorders in the patient ${ }^{(12)}$.

The role of physiotherapy in conservative measures that can be used in osteoarthritis cases includes exercise therapy ${ }^{(13)}$. Exercise therapy, as a physiotherapy modality, can be used to increase muscle strength by providing strengthening exercises. By providing strengthening exercises, there will be an increase in the number of sarcomere and muscle fibers (actin and myosin filaments required for muscle contraction), so that the

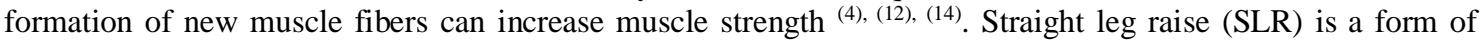
isometric strengthening exercise for the quadriceps muscles with a focus on the rectus femoris muscle ${ }^{(15)}$. Exercises with static bicycles are used to increase muscle strength and increase the range of motion of patients with knee osteoarthritis by increasing muscle mass through consideration of dosages and appropriate biomechanical modifications so that the load or pressure on the joints and articular cartilage is reduced and pain does not increase and joint proprioception improves ${ }^{(4),(16)}$. Based on the aforementioned problems, this study aimed to determine the effect of straight leg raise and static bicycle exercises on the increase in quadriceps muscle strength in patients with knee osteoarthritis.

\section{METHODS}

This study used experimental research with a two-group pretest-posttest design. This research was conducted from April to August 2018 at Salewangan Maros Hospital. The population used was knee joint osteoarthritis patients aged 40-60 years and experienced quadriceps muscle weakness. Samples met the inclusion criteria, namely no history of diseases such as diabetes mellitus, heart defects, and free of other neuromuscular disorders. Subjects with a history of neuromusculoskeletal disorders, osteoarthritis without quadriceps muscle weakness, and reluctance to become subjects until the completion of the intervention were not included. Sampling was done by simple random sampling technique, namely by doing a lot of subject numbers or based on odd or even numbers, so that the sample size was 28 subjects, then randomized into two treatment groups, each of which totaled 14 subjects.

The straight leg raise intervention group was given several training sessions where each training session was carried out for 5-8 minutes with a duration of 30 minutes of exercise three times a week, while the static bicycle exercise was given 30 minutes of light training with a frequency of three times. times a week. All exercises are followed by measuring the length of the exercise using a stopwatch. The data collected were subject characteristics data obtained through direct interviews and quadriceps muscle strength data obtained using manual muscle tests which were carried out twice, namely before and after straight leg raise (SLR) exercise with a stationary bicycle, then analyzed using a comparative analysis in the form of Wilcoxon test was to determine the effects before and after the intervention, while the Mann-Whitney test was to determine the differences in effects between treatment groups.

\section{RESULTS}

This section presents the analysis and interpretation of data collected through direct interviews in response to problems in this study. Based on the results of the analysis showed in Table 1, it is known that the subjects who experience the most knee osteoarthritis accompanied by quadriceps muscle weakness were female patients aged 56-60 years. Thus, the older the subject, the more likely it was to develop osteoarthritis which was accompanied by weakness of the quadriceps muscles. 
Table 1. Characteristics os patient osteoarthritis by sex and age

\begin{tabular}{ccc}
\hline Variable & Frequency & Percentage \\
\hline Sex & & \\
\hline Male & 9 & 32.14 \\
Female & 19 & 67.86 \\
\hline Age (years) & & \\
\hline $40-45$ & 3 & 10.71 \\
$46-50$ & 5 & 17.86 \\
$51-55$ & 8 & 28.57 \\
$56-60$ & 12 & 42.86 \\
\hline
\end{tabular}

Table 2. Quadriceps muscle strength before and after the intervention

\begin{tabular}{cccccccc}
\hline \multirow{3}{*}{ Intervention } & \multicolumn{4}{c}{ Measurement time } & \multirow{2}{*}{ Difference in average } & \multirow{2}{*}{ p-value } \\
\cline { 2 - 5 } & \multicolumn{3}{c}{ Pre-test } & \multicolumn{2}{c}{ Post-test } & & \\
\cline { 2 - 6 } & Mean & SD & Mean & SD & Mean & SD & \\
\hline SLR & 2.70 & 0.483 & 2.80 & 0.422 & 1.10 & 0.061 & 0.002 \\
\hline Static bicycle & 2.80 & 0.422 & 3.60 & 0.516 & 0.8 & 0.094 & 0.005 \\
\hline
\end{tabular}

$\mathrm{SLR}=$ straight leg raise; $\mathrm{SD}=$ standard deviation; Wilcoxon test

Table 2 showed the mean value before and after the intervention shows that there was a difference with the mean value for the straight leg raise (SLR) treatment of $1.10 \pm 0.061$ with p-value of $0.002(<0.05)$ and on the static bicycle exercise $0.8 \pm 0.094$ with p-value of $0.005<0.05$, which means that the provision of straight leg raise (SLR) exercises and stationary bicycle exercises could significantly increase the strength of the quadriceps muscles. Thus the provision of straight leg raise (SLR) exercises and static bicycle exercises had a significant effect on increasing the strength of the quadriceps muscles in patients with knee osteoarthritis.

Table 3. Comparison of quadriceps muscle strength between groups

\begin{tabular}{cccc}
\hline \multirow{2}{*}{ Intervention } & \multicolumn{2}{c}{ Muscle strength after treatment } & \multirow{2}{*}{ p-value } \\
\cline { 2 - 3 } & Mean & SD & \\
\hline SLR & 2.80 & 0.422 & \multirow{2}{*}{0.481} \\
\hline Static bicycle & 3.60 & 0.516 & \\
\hline
\end{tabular}

$\mathrm{SLR}=$ straight leg raise; $\mathrm{SD}=$ standard deviation; Mann Whitney test

The results of data analysis in table 3 show that the p-value $=0.481(>0.05)$, which means that there was no significant difference in effect between the two forms of treatment on the increase in quadriceps muscle strength. Straight leg raise exercises and stationary bicycle exercises did not have a different effect on increasing quadriceps muscle strength in patients with knee osteoarthritis.

\section{DISCUSSION}

Based on the results of the analysis that has been done, it is known that the age and gender factors have a relationship with the incidence of osteoarthritis of a person's knee joint. The results showed that the older a person is, the more likely it is to develop osteoarthritis which is accompanied by weakness of the quadriceps muscles. This can occur because the increasing age of a person will also be accompanied by a decrease in the function of the organs that form the joints, and in the same condition, activities are always carried out throughout the day. This is in line with the results of a study that states that the prevalence and severity of jointforming cartilage increase with increasing age and body mass index ${ }^{(17),(18)}$. The age factor also has a positive correlation with functional disability. This happens because, with increasing age, the components that make up joints decrease in function resulting in pain, movement disorders, and even muscle weakness so that the quality of the function and movement of the organs also decreases. Therefore, the older the age, the greater the level of functional disability ${ }^{(19),(20)}$. Age factor is also closely related to oxidative damage, cartilage erosion, muscle weakness, and a decrease in proprioception ${ }^{(21)}$.

Likewise, analysis of gender factors, shows that female subjects have more knee osteoarthritis than men with an incidence ratio of 1.5-4 times more women than men. This is because hormonal factors and physical activity and body mass index cause differences such as bone density in men and women ${ }^{(22)}$. Hormonal factors in 
women are the effects on hormones as a result of the menstrual cycle and the pregnancy process which affects the levels of endogenous sex hormones which allow women to be at risk of developing osteoarthritis ${ }^{(23),(24) .}$

Data on the effect of straight leg raise (SLR) training and stationary bicycle training showed a significant effect on changes in the increased strength of the quadriceps muscles in subjects experiencing weakness due to knee osteoarthritis. This mechanism can be achieved because giving the straight leg raise exercise stimulation the muscles to actively contract freely. Straight leg raise is open-chain kinetic, which is an active motion exercise that involves one or more muscles and joints without movement in the proximal segment. The longer the leg stretch, the greater the workload on the muscle allowing it to contract maximally (25), (26). Likewise, stationary bicycle exercises can increase muscle strength and reduce pain in the knee. This mechanism occurs because exercise with a stationary bicycle reduces the compression load on the knee joint but puts the burden on the muscles to contract ${ }^{(27)}$. This is evidenced by comparing cycling at high intensity with the same effect as low-intensity cycling to improve function, aerobic capacity and reduce pain, meaning that exercise with a stationary bicycle has a very little load on the joints. Kinesiology studies have also shown that the strength generated by the muscles around the knee when riding a stationary bike is not greater than when walking so that the load generated when cycling is safer for osteoarthritis patients ${ }^{(28)}$.

In the comparison of effects between treatment groups, it was found that there were no significant differences in effects between the two treatment groups. This means that both straight leg raise (SLR) and stationary bicycle exercises have the same effect on increasing the strength of the quadriceps muscles in subjects with knee osteoarthritis. This is in line with the results of kinesiological studies which show that the strength generated by the muscles around the knee when riding a stationary bike is not greater than that when walking so that the load generated when cycling is safer for osteoarthritis patients ${ }^{(28)}$. Both forms of exercise intervention also provide benefits to muscle tissue in the form of stimulation of the Golgi tendon organ (GTO) which carries information on mechanical changes forwarded to afferent fibers so that stability and muscle tone can be maintained. These results are also supported by the results of research by Mangione et al (1999) which states that stationary cycling exercises do not cause acute pain so that functional abilities increase which causes muscle strength and joint range of motion to be increased. Likewise, the results of research by Gezginaslan et al (2018) state that strengthening exercises can increase muscle strength and repair joint proprioception. Thus, both the straight leg raise and static bicycle exercises influence the quadriceps muscle strength of patients with knee osteoarthritis (7), (25), (26), (28).

\section{CONCLUSION}

From the above findings, this study can conclude that the gender factor supported by the age factor of the subject is a factor that has a major contribution to the occurrence of quadriceps muscle weakness in subjects with knee osteoarthritis. Free active exercise contributed significantly to the increase in quadriceps muscle strength in subjects who had knee joint osteoarthritis. Based on the results and conclusions of the study, it is recommended that the importance of preventing excessive physical activity that can increase the workload of the knee joint such as squatting and up and downstairs is recommended, especially in women with older age. Exercises that should be given are free active exercises without putting weight on the knee joints such as straight leg raises and exercises with stationary bikes.

\section{REFERENCES}

1. Kemenkes RI. Laporan Nasional Riset Kesehatan Dasar 2018. Jakarta: Kemenkes RI. 2018.

2. Sarzi-Puttini P, Cimmino MA, Scarpa R, Caporali R, Parazzini F, Zaninelli A, et al. Osteoarthritis: An overview of the disease and its treatment strategies. Semin Arthritis Rheum. 2005;35(1 SUPPL. 1):1-10.

3. Abramson SB, Attur M, Yazici Y. Prospects for disease modification in osteoarthritis. Nat Clin Pract Rheumatol. 2006;2(6):304-12.

4. Fransen M, McConnell S, Harmer AR, Van Der Esch M, Simic M, Bennell KL. Exercise for osteoarthritis of the knee: A Cochrane systematic review. Br J Sports Med. 2015;49(24):1554-7.

5. Pisters MF, Veenhof C, de Bakker DH, Schellevis FG, Dekker J. Behavioural graded activity results in better exercise adherence and more physical activity than usual care in people with osteoarthritis: A cluster-randomized trial. J Physiother [Internet]. 2010;56(1):41-7. Available from: http://dx.doi.org/10.1016/S1836-9553(10)70053-9

6. Misra RK, Batra AV. Clinical and Functional Outcomes of Proximal Fibular Osteotomy on Varus Deformity and Medial Compartment Knee Osteoarthritis. J Arthritis. 2019;8(3):1-4.

7. Gezginaslan Ö, Öztürk EA, Cengiz M, Mirzaoğlu T, Çakcı FA. Effects of isokinetic muscle strengthening on balance, proprioception, and physical function in bilateral knee osteoarthritis patients with moderate fall risk. Turkish J Phys Med Rehabil. 2018;64(4):353-61.

8. Knoop J, Dekker J, van der Leeden M, van der Esch M, Thorstensson CA, Gerritsen M, et al. Knee joint 
stabilization therapy in patients with osteoarthritis of the knee: A randomized, controlled trial. Osteoarthr Cartil [Internet]. 2013;21(8):1025-34. Available from: http://dx.doi.org/10.1016/j.joca.2013.05.012

9. Ismaningsih, Selviani I. Penatalaksanaan Fisioterapi Pada Kasus Osteoarthritis Genue Bilateral Dengan Intervensi Neuromuskuler Taping Dan Strengthening Exercise Untuk Meningkatkan Kapasitas Fungsional. J Ilm Fisioter. 2018;1(2):38-46.

10. Anestherita F. Perbandingan intensitas nyeri, kekuatan otot kuadrisep dan kemampuan fungsional lutut pada obesitas dan tanpa obesitas : studi potong lintang pada perempuan dewasa dengan osteoartritis genu. Tesis [Internet]. 2013;1-100. Available from: http://lib.ui.ac.id/file?file=digital/20351634-SP-Fitri Anestherita.pdf

11. Gustina E, Handani MC, Sirait A. Studi Kasus Kontrol di Rumah Sakit Tk. II Putri Hijau Medan Tahun 2017 American College of Rheumatology sebagai sekelompok kondisi heterogen yang Berdasarkan data Badan Kesehatan Dunia ( WHO ), penduduk yang mengalami. 2017;

12. Hurley M, Dickson K, Hallett R, Grant R, Harari H, Walsh N, et al. Exercise interventions and patient beliefs for people with hip, knee, or hip and knee osteoarthritis: A mixed-methods review. Cochrane Database Syst Rev. 2018;2018(4).

13. Hendrik, Yonathan Ramba AMH. Efek Stimulasi Interferensial Pada Penerapan Latihan Sepeda Statis Terhadap Perubahan Nyeri dan Gerak Sendi Lutut Pasien Osteoarthritis. J Fisioter [Internet]. 2020;20:4653. Available from: https://ejurnal.esaunggul.ac.id/index.php/Fisio/article/view/3454

14. De Paula Gomes CAF, Politti F, De Souza Bacelar Pereira C, Da Silva ACB, Dibai-Filho AV, De Oliveira AR, et al. Exercise program combined with electrophysical modalities in subjects with knee osteoarthritis: A randomized, placebo-controlled clinical trial. BMC Musculoskelet Disord. 2020;21(1):1-11.

15. Nugraha IBA, Kambayana G, Residen D, Ilmu P-1, Dalam P, Rheumatologi D. Prinsip Latihan Penderita Osteoartritis. 2017;44(2):149-53. Available from: http://www.kalbemed.com/Portals/6/23_249PraktisPrinsip Latihan Penderita Osteoartritis.pdf

16. Salacinski AJ, Kelly Krohn, Sco FL, Megan LH, Kathryn Ireland, Gregory Marchei. The effects of group cycling on gait and pain-related disability in individuals with mild-to-moderate knee osteoarthritis: A randomized controlled trial. J Orthop Sports Phys Ther. 2012;42(12):985-95.

17. Davies-Tuck ML, Wluka AE, Wang Y, Teichtahl AJ, Jones G, Ding C, et al. The natural history of cartilage defects in people with knee osteoarthritis. Osteoarthr Cartil. 2008;16(3):337-42.

18. Bricca A, Juhl CB, Steultjens M, Wirth W, Roos EM. Impact of exercise on articular cartilage in people at risk of, or with established, knee osteoarthritis: a systematic review of randomized controlled trials. Br J Sports Med. 2019;53(15):940-7.

19. Başkan BM, Yurdakul FG, Aydın E, Sivas F, Bodur H. Effect of Vitamin D levels on radiographic knee osteoarthritis and functional status. Turkish J Phys Med Rehabil. 2018;64(1):1-7.

20. Palazzo C, Nguyen C, Lefevre-Colau MM, Rannou F, Poiraudeau S. Risk factors and burden of osteoarthritis. Ann Phys Rehabil Med. 2016;59(3):134-8.

21. Li Y, Luo W, Deng Z, Lei G. Diet-Intestinal Microbiota Axis in Osteoarthritis: A Possible Role. Mediators Inflamm. 2016;2016.

22. Jones G, Glisson M, Hynes K, Cicuttini F. Sex and site differences in cartilage development: A possible explanation for variations in knee osteoarthritis in later life. Arthritis Rheum. 2000;43(11):2543-9.

23. Prieto-Alhambra D, Judge A, Javaid MK, Cooper C, Diez-Perez A, Arden NK. Incidence and risk factors for clinically diagnosed knee, hip, and hand osteoarthritis: Influences of age, gender, and osteoarthritis affecting other joints. Ann Rheum Dis. 2014;73(9):1659-64.

24. Hussain SM, Cicuttini FM, Alyousef B, Wang Y. Female hormonal factors and osteoarthritis of the knee, hip and hand: a narrative review. Climacteric [Internet]. 2018;21(2):132-9. Available from: https://doi.org/10.1080/13697137.2017.1421926

25. Houglum PA, Perrin DH. Human Kinetics Athletic trAining educAtion SerieS TherapeuTic exercise for MusculoskeleTal injuries [Internet]. 2010. Available from: www.HumanKinetics.com

26. Carolyn Kisner PT MAPE, The Ohio State University School of Allied Medical Professions Physical Therapy Division Columbus O, COLBY LA. Therapeutic Exercise Foundation and Techniques. 5th ed. Philadelphia: Davis Plus; 957 p.

27. Carol Eustice. No Title Bicycling as Exercise for People With Osteoarthritis. 2019;1-7. Available from: https://www.verywellhealth.com/osteoarthritis-causes-4693618

28. Mangione KK, McCully K, Gloviak A, Lefebvre I, Hofmann M, Craik R. The effects of high-intensity and low-intensity cycle ergometry in older adults with knee osteoarthritis. Journals Gerontol - Ser A Biol Sci Med Sci. 1999;54(4). 